Journal of Science Education Research

Journal homepage: www.journal.uny.ac.id/jser

JSER

\title{
THE EFFECTS OF MODEL PROJECT-BASED LEARNING APPROACH ON STEM (SCIENCE, TECHNOLOGY, ENGINEERING, MATHEMATIC) ON SCIENCE LEARNING TO JUNIOR HIGH SCHOOL STUDENT'S CRITICAL THINKING SKILLS AND COOPERATIVE SKILLS
}

\author{
Riyani Septi Indriyana ${ }^{1} *$ Susilowati $^{2}$ \\ 1,2, Faculty of Mathematics and Natural Sciences, Universitas Negeri Yogyakarta \\ Corresponding Author. Email: septiindri75@gmail.com
}

Keywords:
Critical Thinking,
Project Based
Learning on STEM
Approach,
Cooperation

Keywords:

Critical Thinking,

Approach,

Cooperation

\begin{abstract}
The research aimed to (1) analyzes the effects of model project-based learning approach on STEM (science, technology, engineering, mathematic) on science learning to junior high school student's critical thinking skills and cooperative skills, and (2) analyze how the effects of model project-based learning approach on STEM (science, technology, engineering, mathematic) on science learning to junior high school student's critical thinking skills and cooperative skills. The research was quasi-experimental with a non-equivalent control group design. The population was eighth-grade students of SMP Negeri 1 Berbah. The sample of the study was selected with cluster random sampling techniques and obtained grade-VIII B as an experimental class and grade-VIII $\mathrm{C}$ as a control class. Learning in the experimental class with a project-based learning model was STEM-oriented and the control class used a scientific approach. The data were pretest and posttest of critical thinking and observation sheets of cooperation. The analysis used the normality test, homogeneity test, MANOVA test, and effect size. The results showed that (1) there was an effect of project based learning model on STEM approach on critical thinking skills and cooperative skills of students of SMP Negeri 1 Berbah, (2) the effect of science learning project based learning model on STEM approach on critical thinking and collaborative skill was on medium category.
\end{abstract}

\section{INTRODUCTION}

Education has a very important role in improving human quality. Education also develops along with the times. The 21 st century is experiencing rapid advancement and change, its development is characterized by the existence of advances and technology (Soh, Arsyad \& Osman, 2010). So, the competitiveness and capability must be possessed in dealing with the very complex demands of the 21st century. Therefore, human resources must be well prepared, and one effective way is through education.

The world of education should prepare students with a 21 st-century skill who able to deal with global economic competition (Ratna, 2017, p. 128). But, education that deals with global competition have not been maximally implemented in Indonesia. And, generation in the 21 st century must have 4C skills (communicating, collaboration, critical thinking, and creative thinking).

Critical thinking skills must be possessed and developed in the 21st century. However, the problem today is the low critical thinking skills among students in Indonesia referring to the results of the TIMSS study (Trend in International Mathematics and Science Study). The results of the TIMSS study in 2015 showed that Indonesia ranked 45 out of 50 participating countries, meanwhile, the questions used in the TIMSS study require high- 
level thinking skills, including critical thinking (Private \& Somakim, 2017, p. 114). In short, the low achievement of Indonesia in the TIMSS study results shows the low critical thinking skills of students.

Based on observations made at SMP Negeri 1 Berbah on 4 December 2019, teachers used teachercentered learning in teaching, and students were not directly involved in analyzing, finding, and discovering information. Students find their difficulties in doing problem-solving and difficulty in analyzing when the teacher proposes problems or questions. The results of daily tests of science that require analysis and interpretation are mostly below the score of Minimum Mastery Criteria (KKM) of 76. Of 128 students, only $2.3 \%$ (3 students) have reached the KKM score, and 97\% (125 students) have not reached the score of KKM. This finding shows the low category on the aspect of critical thinking skills of interpretation and analysis of students in SMP N 1 Berbah.

According to Hapsari and Yonata (2014, p.2), cooperative skills must be taught to students as it is a useful skill to improve group work and key to success to blend into the community.

Based on observations made by researchers at SMP Negeri 1 Berbah on December 4, 2019, students disagree with divided groups that selected randomly as they felt not close to interaction to peer. Students tend to behave individually which showed by students who are not active in the group. For example, there are 6 students in a group, only 4 students are active. In the presentation session, the results of the discussion are not delivered properly due to only active students to understand the results of the task. While in group learning, students should cooperate so that all group members understand the material. This finding shows the low critical thinking of cooperative skills on aspects of contributing and being responsible among students in SMP N 1 Berbah.

In learning science, students should lead towards thinking skills to answer problems. So, learning science must able to establish knowledge and make students be critical thinkers. Cooperative skills will influence students in a group to solve problems collaboratively.

The project-based learning model is projectbased learning collaboratively in heterogeneous groups, focused on questions that lead students to use concepts or principles through experience. By this method, it could produce real work which leads to the process. Stages of project-based learning are; start with the essential (presenting the problem), design a plan for the project (making a plan), creates a schedule (arranging scheduling), monitor the students and the progress of the project (monitoring project), assess the outcome (assess), evaluate the experiences (evaluation).

Learning with the STEM approach consists of five namely science, technology, engineering, mathematic. The selection of material refers to the characteristics of STEM. Substance pressure is a natural science material that able to be taught using the STEM approach, namely on science in finding knowledge. Second, technology related to the technology applied to the material of submarines and hydraulic pumps. Then, engineering related to engineering design regarding the manufacture of materials equipment, namely submarines and hydraulic pumps. And, mathematic is used to analyze and reasoning mathematical equations related to the concept of pressure material and in its calculations.

It is important to learn to develop critical thinking skills and collaborative skills, such as project-based learning. Project-based learning is learning to improve critical thinking skills. Critical thinking is a personal skill in analyzing an idea using logical reasoning (Ratna, 2017, p.2). Through this thinking, the activity can emerge critical thinking skills in students. Also, the project-based learning model can emerge cooperative skills due to the heterogeneous groups. Supported by Pratiwi and Ardianti (2018, p.5), states that the project-based learning model can improve student collaboration. In line with Marza, Adnan, \& Fitria (2019, p.6), there is an influence from the application of the project-based learning model to critical thinking skills and collaborative skills. And, Khoiriyah, Abdurrahman \& Wahyudi (2018, p.9) shows that STEM learning can significantly improve students' critical thinking.

Based on the background, researchers interested to determine the analyzes the effects of model project-based learning approach on STEM (science, technology, engineering, mathematic) on science learning to junior high school student's critical thinking skills and cooperative skills of students of SMP Negeri 1 Berbah. The particular research is important to publish. The research used as an illustration of how to improve critical thinking and collaborative skills. Another point stated in this study is the effects of model project-based learning approach on STEM (science, technology, engineering, mathematic) on science learning to junior high school student's critical thinking skills and cooperative skills of students of SMP Negeri 1 Berbah.

\section{METHOD}

Types of research 
The research was a quasi-experimental study.

\section{Time and Place of Research}

This research was conducted in DecemberFebruary 2020 in SMP N 1 Berbah.

\section{Population and Sample}

The population was 128 students of gradeVIII even semester in SMPN 1 Berbah academic year 2019/2020 which divided into 4 classes, namely class VIII-A, VIII-B, VIII-C, and VIII-D. The sampling technique used cluster random sampling and selected grade-VIII-B as an experimental class and grade-VIII $\mathrm{C}$ as a control class.

\section{Research Procedure}

The research design was the nonequivalent control group design. Nonequivalent control group design has two types, namely nonequivalent control group pretest-posttest design and nonequivalent control group posttest-only design (Privitera and Delzell, 2019, p.39).

Table 1 . The research design of the

nonequivalent control group pretest-posttest on critical thinking skills data

\begin{tabular}{ccc}
\hline $\mathrm{O}_{1}$ & $\mathrm{X}_{1}$ & $\mathrm{O}_{2}$ \\
\hline $\mathrm{O}_{3}$ & $\mathrm{X}_{2}$ & $\mathrm{O}_{4}$ \\
\hline
\end{tabular}

Source: Sugiyono (2018, p.116)

Table 2. The research design of posttest-only design nonequivalent control group on cooperative skills data.

\begin{tabular}{cc}
\hline $\mathrm{X}_{1}$ & $\mathrm{O}_{2}$ \\
\hline $\mathrm{X}_{2}$ & $\mathrm{O}_{4}$ \\
\hline
\end{tabular}

Sources: Privitera and Delzell (2019, p.339)

Where:

$\mathrm{O} 1$ = measurement of the initial ability of the experimental group

$\mathrm{O} 2$ = measurement of the final ability of the experimental group

$\mathrm{X} 1$ = learning with project-based learning approach on STEM in the experimental group

$\mathrm{X} 2$ = scientific learning in the control group

$\mathrm{O} 3$ = measurement of the initial ability of the control group

$\mathrm{O} 4=$ measurement of the final ability of the control group.

\section{Research Instruments}

Data collection instrument was pretest and posttest of critical thinking skills to determine the influence of project-based learning on students' critical thinking skills; observation sheets of collaborative skills used to determine the effect of learning on project-based learning on critical thinking skills; and observational sheets of implementation learning.

\section{RESULT}

\section{The Implementation of Science learning using Project-Based learning on STEM Approaches}

In the implementation of learning, data obtained from the results of the observation sheet following the RPP (Lesson Plan). Table 5 showed the result of the implementation of learning using project-based learning on the STEM approach.

Table 5. Implementation of learning on Experiment and Control Class

\begin{tabular}{ccccc}
\hline Class & $\begin{array}{c}\text { Meet } \\
\text {-ing }\end{array}$ & $\begin{array}{c}\text { Implementati } \\
\text { on }(\%)\end{array}$ & $\begin{array}{c}\text { Mea } \\
\mathrm{n}\end{array}$ & $\begin{array}{c}\text { Categor } \\
\mathrm{y}\end{array}$ \\
\hline Experime & 1 & 94,74 & & Very \\
nt & 2 & 100 & & Good \\
& 3 & 94,44 & 95,8 & \\
& 4 & 94,12 & 2 & \\
Control & 1 & 95 & & Very \\
& 2 & 92,86 & 93,4 & Good \\
& 3 & 93,75 & 8 & \\
& 4 & 92,31 & & \\
\hline
\end{tabular}

\section{Effects of Science learning using Project-Based learning on STEM Approaches}

Data on critical thinking skills obtained from the score of pretest and posttest. Then, the score of students' pretest and posttest analyzed to gain a normalized N-Gain score with the aim to determine the improved critical thinking skills. Figure 1 shows a picture of the N-Gain score of pretest and posttest calculation:

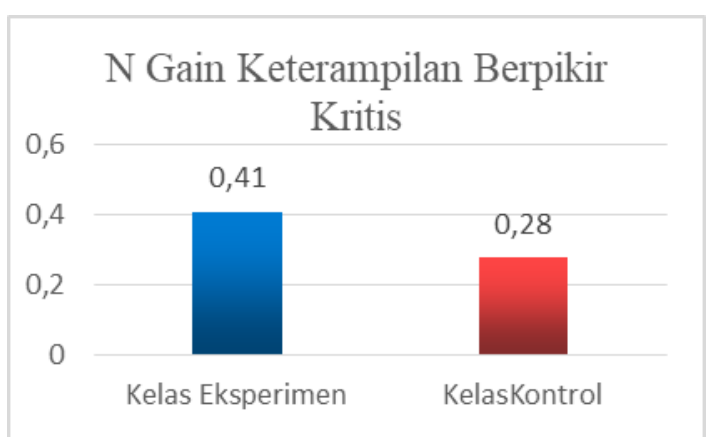

Figure 1. Score of N-Gain in Critical Thinking Skills

Based on Figure 1, the normalized N-Gain score is known if the increasing score of critical 
thinking skills in the experimental class has a score of 0.41 in the medium category, meanwhile, in the control class has a score of 0.28 in the low category.

The score of each aspect of critical thinking is seen from the mean of each aspect of critical thinking.

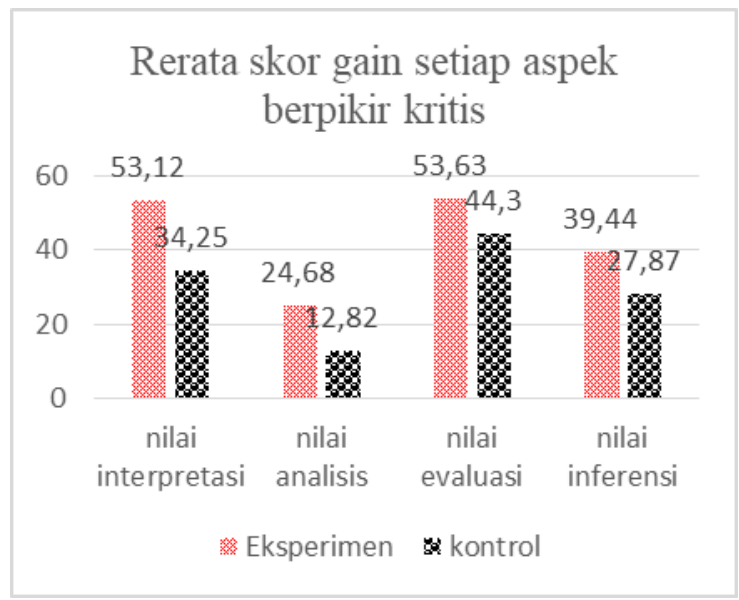

Figure 2. Mean of Aspects of Critical Thinking Skills

The interpretation aspect shows the score of the experimental class is higher than the control class. When students design projects, skills in the aspect of interpretation can develop as students designing projects in the group understand the experience, and interpret the work procedures well. According to Nur (Lambertus, 2009, p.2), critical thinking skills refer to special abilities obtained through experience or training to perform certain tasks.

The aspect of analysis in the experimental class is higher than the control class. In the experimental class, the students were able to identify the relationship between the application and the legal concept of Archimedes during the projects. According to Facione (1990, p.13), aiming to measure the critical thinking ability in terms of the analysis aspects is assessed on information, facts, or ideas that students make based on the problem given to the problem.

The evaluation aspect of the experimental class is higher than the control class. In the experimental class, there is a final phase in which students evaluate and reflect the learning. According to Hidayati, As'ari, and Daniel (2016, p.2), it needs reflective thinking in the evaluation phase.

The inference aspect shows the score of the experimental class is higher than the control class. Students in the experimental class conclude with appropriate and logical reasons. In line with Hidayati, As'ari, and Daniel (2016, p.2) inference requires logical thinking. According to Arini and Juliadi (2018, p.11) states, if the aspect of inference has the lowest score than other aspects, so the inference in students is low due to a low ability to connect a problem with the solution.

Effects of Project Based Learning on STEM on Collaborative Skills

Cooperative skills are shown in three aspects; contribution, responsibility, and mobilization of abilities to the maximum (West, 2002, p.41). In this study, collaborative skills were measured using an observation sheet filled by observers. Figure 3 is the mean of observation of the collaborative skills in the experimental and the control class.

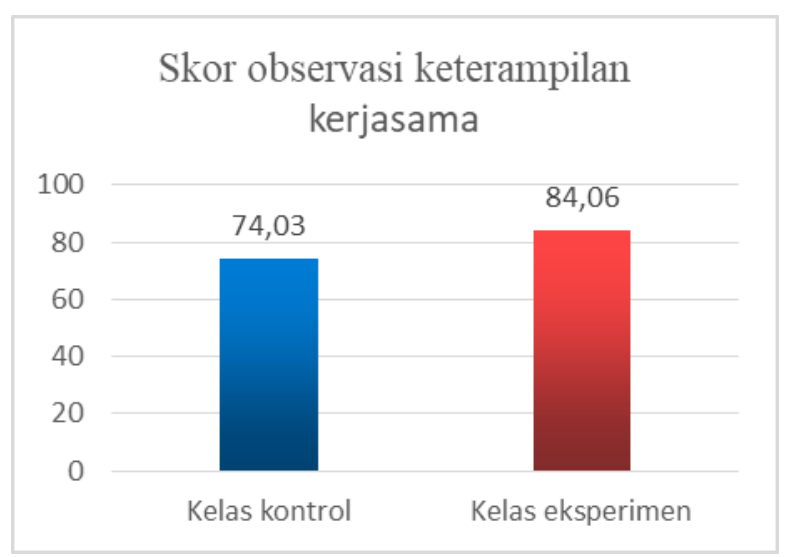

Figure 3. Results of the Cooperative Observation Sheet

The inference aspect shows the score of the experimental class is higher than the control class. Students in the experimental class conclude with appropriate and logical reasons. In line with Hidayati, As'ari, and Daniel (2016, p.2) inference requires logical thinking. According to Arini and Juliadi (2018, p.11) states, if the aspect of inference has the lowest score than other aspects, so the inference in students is low due to a low ability to connect a problem with the solution.

Effects of Project Based Learning on STEM approach on Collaborative Skills

Cooperative skills are shown in three aspects; contribution, responsibility, and mobilization of abilities to the maximum (West, 2002, p.41). In this study, collaborative skills were measured using an observation sheet filled by observers. Figure 3 is the mean of observation of the collaborative skills in the experimental and the control class.

Based on Figure 3, the highest mean in the experimental class shows that students who learn using project-based learning models on STEM have a higher score of collaborative skills. According to Hapsari and Yonata (2014, p.2), cooperative skills must be taught to students as it is a useful skill to improve group work and key to success to blend into the community. 


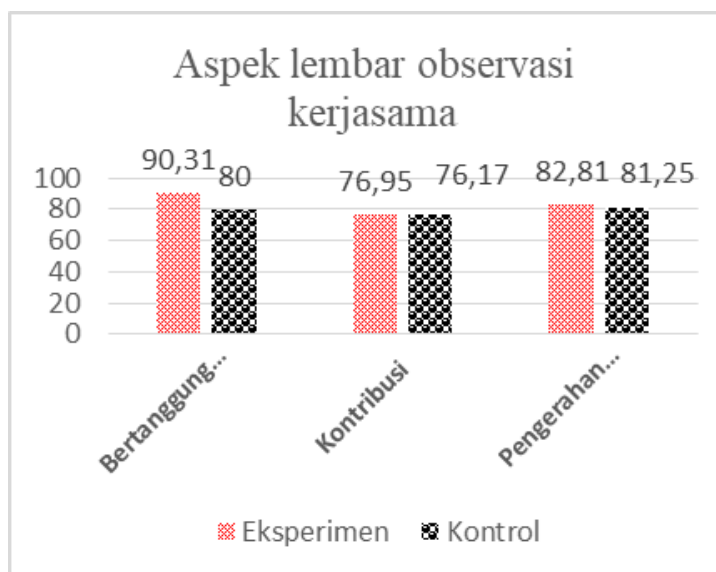

Figure 4. Observation Sheet of Cooperative Aspects

Based on Figure 4, the experimental class has a higher score on the aspect of responsibility than the control class. The finding is seen when the students carry out the tasks according to their respective parts and have the responsibility to achieve the goal of group collaboration. According to West (2002, p.41), the collaborative responsibility to complete the work is by giving responsibilities to create a good cooperation.

In the aspect of the contribution of the experimental class is higher than the control class. In the experimental class, the students give ideas related to the preparation of the project and find solutions to the problems. According to West (2002, p.41), by contributing both energy and thought, cooperation will be successfully created.

The aspect of maximum ability interference in the experimental class is higher than the control class. In the experimental class, the project of students finish on time and help one another when friends in the group need help. According to West (2002, p.41), by maximizing the ability of each team member, cooperation will be solid and more quality.

Effects of Project Based Learning on STEM approach on Critical Thinking and Collaborative Skills

Data from the score of pretest and posttest on critical thinking skills and observation sheets of collaborative skills analyzed using the MANOVA test through the SPSS version 22 program. MANOVA is a test to measure the effect of categorical independent variables on several dependent variables on a quantitative scale (Ghozali, 2009, p.79). The criterion in the MANOVA test is; H0 accepted if $\mathrm{Sig}>\alpha$ and H0 rejected if Sig $<\alpha$. The MANOVA test aimed to determine the effect of learning using Project-Based Learning on the STEM approach on Critical Thinking and Collaborative Skills. The result showed that the significance score of critical thinking skills was 0.029 and the significance score of cooperative skills was 0.028 less than 0.05 . So, there is an influence on project-based learning on the STEM approach to critical thinking skills and collaborative skills. Moreover, the score of effect size on critical thinking skills was 0.55 and collaborative skill was 0.56 in the medium category because the differences on the mean of the control and experimental class in critical thinking and cooperative do not show a significant difference, but, the experimental class has higher mean than the control class. According to Rosnow and Rosenthal (2003, p.237), the factors affect the effect size are; the humans are multidimensional and are influenced by many factors in which these factors interact with each other. The research on humans is difficult regardless of the influence of the environment so there must be an error or bias in the research.

In short, the study shows the influence of the project-based learning model on STEM on critical thinking and collaborative skills. During learning using a project-based learning model, students are actively involved, discussion with peers, analyze the project, looking for reference through a laptop, and asking. Then, students work collaboratively and help each other in the group during the making project in the experimental class.

Science learning with a project-based learning model on a STEM approach integrates four fields, namely science, technology, engineering, and mathematics, which can improve critical thinking skills and collaborative skills. According to Ida (2013, p.2), learning with a project has enormous potential to train students' thinking processes that lead to students' critical thinking skills. Critical thinking skills developed at each stage of the learning model of project learning. Students become encouraged in their learning. The teacher acts as a mediator and facilitator. In the project-based learning on the STEM approach, the experimental class allowed us to determine the design and technique. In line with Afifah, Ilmiati, and Toto (2019, p.4), using a project-based learning model combined on the STEM approach improves students' critical thinking skills because the activities in learning are more oriented towards involvement active students, to stimulate students to think critically. According to Pratiwi, Ardianti, and Kanzunnudin (2018, p.4), learning activities with the project model have benefits for students to increase collaboration with friends in making assignments.

\section{CONCLUSION}




\section{Conclusion}

Based on the results and discussion, concluded that (1) there was an effect of a projectbased learning model on a STEM approach on critical thinking skills and cooperative skills of students of SMP Negeri 1 Berbah, (2) the effect of science learning project-based learning model on STEM approach on critical thinking and collaborative skill was on medium category.

\section{Suggestion}

The article proposed suggestions are (1) conducting a review, especially at the grade level that will be taught using learning science-based on project-based learning models with STEM which aims the learning well implemented (2) the need for further research to know the effect, increase or the effectiveness of project-based learning with STEM approaches on critical thinking and collaborative skills.

\section{REFERENCES}

Afriana, J., Permanasari., \& Fitriani. (2016). Penerapan Project Based Learning Terintegrasi STEM untuk Meningkatkan Literasi Sains Siswa Ditinjau dari Gender, Jurnal Inovasi Pendidikan, 2 (XX), 5-9.

Afifah, A ., Ilmiyati, N., \& Toto. (2019). Model Project Based Learning Berbasis STEM Untuk Meningkatkan Penguasaan Konsep dan Keterampilan Berpikir Kritis Siswa, Jurnal Pendidikan Biologi, 11 (XX), 3-6.

Arini, W., \& Fikri, J. (2018). Analisis Kemampuan Berpikir Kritis Pada Mata Pelajaran Fisika Untuk Pokok Bahasan Vektor Siswa Kleas X SMA Negeri 4 Lubuklinggau, Jurnal Berkala Fisika Indonesia, 1 (XX), 5-9.

Facione, P. A. (1990). Critical thinking: A Statement Of Expert Consensus for Purposes of Educational Assessment And Instruction. Millbrae, CA: The California Academic Press.

Ghozali, I. (2009). Aplikasi Analisis Multivariate Dengan Program SPSS. Semarang: Badan Penerbit Universitas Diponegoro

Hapsari, N, \& Yonata, B. (2014). Keterampilan Kerjasama Saat Diskusi Kelompok Siswa Kelas XI IPA pada Materi Asam Basa Melalui Penerapan Model Pembelajaran Kooperatif di SMA Kemala Bhayangkari 1, Unesa Journal of Chemical Education, 3 (XX), 4-7.

Hidayati, D., As'ari, A., \& Daniel, T. (2016). Analisis Kemampuan Berpikir Kritis Siswa SMP Kelas IX Pada Materi Kesebangunan,
Konferensi Nasional Penelitian Matematika dan Pembelajarannya UMS, 5-9.

Ida, A., Sadia, W., \& Muderawan. (2013). Pengaruh Model Pembelajaran Berbasis Proyek Terhadap Pemahaman Konsep Kimia dan Keterampilan Berpikir Kritis, e-Journal Program Pascasarjana Universitas Pendidikan Ganesha, 3 (XX), 5-8.

Khoiriyah, N., Abdurrahman., \& Wahyudi. (2018). Implementasi Pendekatan Pembelajaran STEM untuk Meningkatkan Kemampuan Berpikir Kritis Siswa SMA pada Materi Gelombang Bunyi, Jurnal Kpf UAD, 5 (XX), 6-9.

Lambertus. (2009). Melatih Keterampilan Berpikir Kritis Dalam Pembelajaran Matematika Di SD. Jurnal Forum Kependidikan, 28 (XX), 25.

Lee, A. (2000). Effect Size Measure for Two Independent Groups. Jurnal Effect Size Bocker, 3 (XX), 1-2.

Marza, A., Adnan, F., Fitria \& Montesari, M. (2019). Pengaruh Model Project Based Learning Terhadap Kemampuan Berpikir Kritis dan Kerjasama Siswa Pada Pembelajaran Tematik Terpadu Kelas VI SD, Jurnal Basicedu, 3 (XX), 4-6.

Pratiwi, I., Ardianti, S., \& Kanzunnudin, M. (2018). Peningkatan Kemampuan Kerjasama melalui Model Project Based Learning (PjBL) berbantuan Metode Edutainment Pada Mata Pelajaran Ilmu Pengetahuan Sosial, Jurnal Refleksi Edukatika, 8 (XX), 177-182.

Pribadi, Adi., Somakim., Yusup, M. 2017. Pengembangan Soal Penalaran Model TIMSS Pada Materi Geometri dan Pengukuran SMP. Jurnal Pendidikan Matematika, 2 (XX), 115128.

Privitera, G\& Delzell. (2019). Quasi-Experimental and Single-Case Experimental Design Chapter Thirteen. California: Sage Publication Inc.

Ratna, H., et all. (2017) Critical Thingking Skill: Konsep dan Indikator Penilaian. Jurnal Taman Cendekia, 1 (2), 6-12.

Rosnow, R., \& Rosenthal, R. (2003). Effect sizes for experimenting psychologists. Canadian Journal of Experimental Psychology, 57 (XX), 221-237.

Soh, T., Arsad, N., \& Osman, K. (2010). The relationship of 21 st century skills on students' attitude and perception towards physics, Procedia Social and Behavioral Sciences, 7 (XX), 546-554.

Sugiyono. (2018). Metode Penelitian Kuantitatif, Kualitatif, dan $R \& D$. Bandung: Alfabeta.

West, M. (2002). Kerja Sama Kelompok yang Efektif. Yogyakarta: Penerbit Kanisius 
Riyani Septi Indriyana, Susilowati/ JSER 2020, 4(1), 11

Widyoko, E.P. (2017). Evaluasi Program Pembelajaran. Yogyakarta: Pustaka Pelajar. 